\title{
ALTERNATIVE TO THE UNIVERSITY: ACADEMY'S COLLEGE OF VLADIMIR G. ORLOV (1770)
}

\author{
Tatiana V. Kostina \\ Saint Petersburg Institute of History of Russian Academy of Sciences, Saint Petersburg, Russian Federation
}

\begin{abstract}
Introduction. In the second half of the 1760s - the first half of the 1770s Ivan I. Betskoy implemented a far-reaching reform of Russian education. It appeared that the problems of two Russian universities had not been the key issues of the reform. Apparently, that was the reason why they were not previously considered as a part of the systemic pan-European crisis in higher education, which had been caused by a need to secularize universities and start teaching in national languages into them, as well as by the general development of sciences, especially physical and cameral ones. Methods and materials. The article for the first time analyzes the model of the Academy's College created at the Petersburg Academy of Sciences in 1770 to replace the Academy's university that had ceased to exist in 1767. Based on the "Privileges and Statute of the Saint Petersburg Imperial Academy of Sciences" (1770), the research proves that this document compiled by Vladimir G. Orlov was partially brought into action without any legislative approval. Analysis. According to the Orlov's Statute, Academy's College appeared at the Academy to reproduce scientists who represented science, but not liberal arts which coincided with the new trend of the Academy of Sciences. It was arranged according to the model common to all education institutions reformed under Ivan I. Betskoy. After completing the main course of study, students were renamed as élèves and assigned to particular academicians for the improvement in science. At the same time, they attended public science courses, which corresponded to the university program in science and since then were allowed to be read not only in Latin and Russian (as in the Statute of 1747), but also in new European languages. Results. Hence, an alternative model of training academic staff, which meant a higher educational level, was created at the Academy of Sciences.

Key words: gymnasiums, Ivan I. Betskoy, history of education, history of the Russian Academy of Sciences, history of universities, Russia in the $18^{\text {th }}$ century, colleges.

Citation. Kostina T.V. Alternative to the University: Academy's College of Vladimir G. Orlov (1770). Vestnik Volgogradskogo gosudarstvennogo universiteta. Seriya 4. Istoriya. Regionovedenie. Mezhdunarodnye otnosheniya [Science Journal of Volgograd State University. History. Area Studies. International Relations], 2020, vol. 25, no. 2, pp. 44-55. (in Russian). DOI: https://doi.org/10.15688/jvolsu4.2020.2.3
\end{abstract}

УДК 94(470+571)“1760/1770”:378

Дата поступления статьи: 03.02.2020

ББК $63.3(2) 51-3$ Дата принятия статьи: 28.03.2020

\section{АЛЬТЕРНАТИВА УНИВЕРСИТЕТУ: АКАДЕМИЧЕСКОЕ УЧИЛИЩЕ В.Г. ОРЛОВА (1770)}

\author{
Татьяна Владимировна Костина \\ Санкт-Петербургский институт истории РАН, \\ г. Санкт-Петербург, Российская Федерация
}


статье на основе малоизученного источника - «Привилегий и Устава Санктпетербургской императорской Академии наук» (1770). Выявлено, что этот документ, составленный В.Г. Орловым, был частично введен в действие в Академии наук, причем благодаря тому, что он занимал должность директора Академии наук и был доверенным лицом Екатерины II. По новому уставу, в Академии появлялось училище с целью воспроизводства ученых, которые в Академии наук представляли физико-математические и естественно-научные дисциплины. Академическое училище было устроено по модели, общей для всех учебных заведений, реформируемых при И.И. Бецком. В его программу были включены и базовые курсы философского факультета. Пройдя основной курс обучения, учащиеся переименовывались в элевов и закреплялись за конкретными академиками для совершенствования в науках. При этом они посещали публичные курсы наук, соответствующие университетской программе по физико-математическому и естественно-научному направлениям, которые отныне разрешено было читать не только на латинском и русском языках (как по Регламенту 1747 г.), но и на новых европейских языках. Таким образом, при Академии наук создавалась альтернативная университетской модель подготовки научных кадров, подразумевающая высшую образовательную ступень.

Ключевые слова: гимназии, И.И. Бецкой, история образования, история Российской академии наук, история университетов, Россия в XVIII в., училища.

Цитирование. Костина Т. В. Альтернатива университету: Академическое училище В.Г. Орлова (1770) // Вестник Волгоградского государственного университета. Серия 4, История. Регионоведение. Международные отношения. - 2020. - Т. 25, № 2. - C. 44-55. - DOI: https://doi.org/10.15688/jvolsu4.2020.2.3

Введение. Во второй половине 1760-х первой половине 1770-х гг. в ряде стран Европы произошел кризис системы образования в целом и университетской модели в частности. В университетах он был вызван необходимостью секуляризации (происходило изгнание иезуитов), общим развитием наук (особенно физических и камеральных), просветительской критикой «латинского» образования и сопровождался поиском новых моделей высшего образования [8, с. 76-77, 85, 287; 39, р. 626635]. Тесная связь Екатерины II с европейскими просветителями способствовала тому, что процесс поиска альтернативных решений шел в России синхронно с другими европейскими странами [40, р. 397-407; 41, р. 592-593, 602-604; 42, p. 260; 44, p. 51-56].

К этому времени в России ощущалась потребность в реформе высшего образования. В Академическом и Московском университетах, где во второй половине 1750-х - начале 1760-х гг. число студентов незначительно, но росло, к середине 1760-х гг. оно вновь показало критически низкие отметки [13, с. 123-207; 38 , с. 37]. Одновременно шли обсуждения различных проектов уставов Московского университета и Академии наук, но большинство из них носило теоретический характер и предлагаемые меры почти не доходили до практического применения [25; 32; 33, с. 56-82; 45]. Реальные изменения, по меньшей мере в Академии наук, произошли в период масштабной реформы учебных заведений И.И. Бецкого, но остаются почти неизученными. Реформа Академии наук и ее учебных учреждений, как и вообще высшее образование, находясь на периферии преобразований, ранее почти не привлекала внимания исследователей, а «Привилегии и Устав Санктпетербургской императорской Академии наук» (1770) В.Г. Орлова, хотя и были изданы, не анализировались как часть этой реформы [36, с. 482-509]. Ранее в историографии констатировалось лишь, что Академический университет прекратил свое существование в 1767 году. Автором статьи описана механика его закрытия (об этом подробнее см.: [10]). В этой работе впервые поставлена задача проанализировать модель учебного заведения, образованного на базе Академии наук взамен университета для подготовки научных кадров.

Методы, источники и историография. Как же получилось, что «Привилегии и Устав Санктпетербургской императорской Академии наук» (далее - Устав Орлова) остались документом, хотя и изданным, но малоизученным и недооцененным? Почему даже внешнюю и внутреннюю критику источника, его позитивистский анализ приходится впервые выполнять в этой статье, понимая, что его судьба может служить отличной призмой для рассмотрения вопроса о стратегиях властвования Екатерины II, о расхождениях, которые существовали в России века Просвещения, между конфирмованным законодательством и реальными практиками управления и распределения ресурсов? 
Причины, на мой взгляд, кроются в следующем. Во-первых, учебные заведения Петербургской академии наук вообще оказались на периферии исследовательских полей, вытесненные историей самой Академии наук с одной стороны и Московским университетом с другой [12]. А во-вторых, что даже более важно, такое положение обусловлено отсутствием этого документа в фондах Санкт-Петербургского филиала Архива РАН (далее СПбФ АРАН) - архива, где сохранился основной массив источников по истории Академии наук XVIII века. По-видимому, из делопроизводства Академии наук подлинный документ был изъят в 1783 г., после чего передан в созданную 7 ноября 1782 г. Сенатскую комиссию по расследованию дел в Академии наук под руководством генерал-прокурора А.А. Вяземского. Г.И. Смагина описала в книге «Сподвижница великой Екатерины», как в момент передачи документов возник конфликт между А.А. Вяземским и директором Академии Е.Р. Дашковой. Последняя отказывалась предоставить в комиссию подлинники действовавших уставных документов и просила «направить в Академию сенатских служащих для изготовления копий. А.А. Вяземский в резкой форме отказал, и Дашковой пришлось подчиниться» [35, с. 52]. В связи с этим академическое делопроизводство, изучаемое в первую очередь обращавшимися к теме исследователями, осталось без важного для истории Академии наук комплекса документов, который в ее фонды так и не вернулся.

Подлинник документа разыскать пока не удается, хотя такие попытки предпринимались в СПбФ АРАН и РГАДА. Известна лишь копия, сделанная в Академии исполняющим обязанности секретаря Академии регистратором М.В. Лебедевым для рядового члена Сенатской комиссии - графа А.Р. Воронцова (брата Е.Р. Дашковой), которая находится в Архиве Санкт-Петербургского института истории $[19$, л. 57 - 84 об.]. Копия включена в конволют, на корешке которого вытиснены золотом слова «О новом положении Академии наук». Основная часть конволюта разделена на два раздела. Первый назван «Учреждении, по которым делались и делаются исполнении». В него вошли документы, разработанные при директоре Академии В.Г. Орлове: «Учрежде- ния до географическаго Департамента касающиеся, учиненныя с учреждения Комиссии по 1775 год; Наказ Географическому департаменту» [19, л. 28-40], «Новое Учреждение гимназии при Императорской Академии наук» $[19$, л. 41-44], «Мнение о книжной лавке» [19, л. 45 - 50 об.], «Новое распоряжение Типографии» $[19$, л. 51 - 56 об.], «Привилегии и Устав Санктпетербургской императорской Академии наук» [19, л. 57 - 84 об.]. Второй раздел назван «Учреждения, сделанныя применяясь к сочиненному вновь регламенту, но оставленныя без исполнения, потому что оной не конфирмован» [19, л. 85 - 135 об.].

В конце устава скопированы подписи, первая из которых - самого В.Г. Орлова. За ней следует приписка: «Сочиненныя преимущества и устав директором Академии наук, графом Владимиром Григорьевичем Орловым, мы нижеподписавшиеся читали и во всем с ними согласны», после чего перечислены подписи академиков К.-Ф. Вольфа, С.К. Котельникова, Э. Лаксмана, А.П. Протасова, С.Я. Румовского, И.-Э. Фишера и адъюнктов В.-Л. Крафта и А.-И. Лекселя. Это означает, что документ был подписан в период не ранее декабря 1769 г. (возвращение в Петербург Э. Лаксмана) и не позднее 8 апреля 1771 г., когда состоялось назначение В.-Л. Крафта, А.-И. Лекселя, И.И. Лепехина и И.-А. Гильденштедта академиками. В заглавие статьи вынесен 1770 г., потому что на протяжении этого года отдельные положения устава вводились в действие в учебных заведениях Академии наук.

Этот документ, хотя и редко, но фигурирует в литературе. Его находили и изучали авторы очерков в «Истории Академии наук СССР» А.В. Предтеченский и Е.С. Кулябко, но посчитали его неосуществленным проектом $[9$, с. $319 ; 19$, лист использования]. По этой же причине, как неконфирмованный устав, в 1974 г. Е.С. Кулябко не включила его в сборник документов «Уставы Академии наук СССР. 1724-1974» [37]. Как следствие, его, например, не увидели Ю.Д. Марголис и Г.А. Тишкин, занимавшиеся учебными заведениями Академии наук. Они делали свои выводы о структуре учебных заведений в последней трети XVIII в. на основе изучения их практической деятельности [16; 17]. Г.И. Смагина при публикации также посчитала проект нереализо- 
ванным. Вслед за А.В. Предтеченским она подчеркивает, что Л. Эйлер, его сын И.А. Эйлер и Я. Штелин не согласились с проектом, внесенным В.Г. Орловым, не поставили на нем свои подписи, поэтому «Устав не получил одобрения у Екатерины II, хотя утверждение его могло бы значительно оживить научноорганизационную деятельность Петербургской Академии наук» [36, с. 481].

Почему Екатерина II не конфирмовала документ? Это могло произойти из-за его непродуманности, заметной законодателям. Она проявилась, например, в разнобое наименований учащихся высших классов то «воспитанниками», то «питомцами», то «элевами». Могли быть и другие причины. В частности, современникам была важна не только публикация того или иного указа, но и его литературные достоинства [23, л. 118]. В свою очередь, в Уставе Орлова есть неудачные формулировки, например: «представляющие написав имя представляемого или представляемых» [19, л. 64].

Главное, конфирмация Устава Орлова неминуемо вызвала бы раскол в среде академиков, ведь независимо друг от друга составлялось два совершенно разных проекта. Дж. Ларокка, работая в ОР РНБ, нашла черновой автограф Я. Штелина к крупному знатоку древностей Ланчиллотто Кастелли, который она датирует июлем 1770 года. В нем Я. Штелин писал: «Из нового плана Академии не будет более исключено полностью изучение словесности, ибо будет восстановлен отдельно класс Истории и словесности, которые, откровенно говоря, игнорировались с некоторого времени, а именно со смерти профессора Байера, автора “Истории Осроены”»". При этом Устав Орлова, несмотря на увеличение числа действительных членов Академии до двадцати, предполагал наличие только двух классов - математического и физического [19, л. 63 - 63 об.].

Тем не менее сопоставление текста Устава Орлова с переменами, произведенными в Академии наук, показало, что по меньшей мере частично он был введен в действие. Это вполне соответствовало духу и букве именного Указа от 6 октября 1766 г., согласно которому В.Г. Орлов назначался директором Академии наук и «доверенной персоной», «чрез которую бы Ея величество даваемые свои повеления оной Академии объявлять, так и нужды ея ведать смогли» [20]. Причем передачу Академии наук «в собственное свое ведомство» Екатерина II производила «для учинения в ней реформы» [20].

В пользу того, что Устав Орлова частично действовал, свидетельствуют его нахождение в бумагах Сенатской комиссии А.А. Вяземского среди среди документов, «По которым делались и делаются исполнении», и кадровые перестановки, произведенные В.Г. Орловым за 1767-1771 гг.: им было назначено 9 академиков, в том числе по экономии и химии. Для сравнения: за пять лет до этого было назначено только 3 академика, а за пять лет после 1771 г. - ни одного. Кроме того, новый бюджет Академии наук на 1771 г., составивший 75000 руб., что совпадало с указанной в уставе суммой расходов, был представлен на заседании Конференции В.Г. Орловым вместе с отчетом Академии за 1767-1769 гг. и единодушно поддержан $[14$, с. $582 ; 24$, с. $795-$ 797]. Убеждают в этом и структурные изменения, произведенные В.Г. Орловым в Академии наук для превращения ее учебных заведений в училище. Эти структурные изменения и станут предметом анализа в данной статье.

Анализ. Что же собой представляли нововведения В.Г. Орлова по отношению к учебным заведениям? Реформируемое учебное заведение в Уставе Орлова названо училищем. Правовая коллизия, возникшая от того, что документ не был конфирмован, объясняет разнобой источников в наименовании учебных заведений Академии после 1770 года. На практике в официальных документах, предназначенных для внешнего использования, учебное заведение называли гимназией, в соответствии с последним конфирмованным Регламентом 1747 года. Например, от имени гимназии публиковались все объявления в «Санктпетербургских ведомостях» [26, с. $5 ; 27$, с. $4 ; 28$, с. 6 ; 29 , с. $6 ; 30$, с. $9 ; 31$, с. 11]. В то же время внутри Академии учебные заведения с 1770 г. именовали училищем [2, л. $102 ; 4$, л. $53 ; 5$, л. 200].

Работа университета при Академии наук Уставом Орлова не возобновлялась. Соответственно, больше в делопроизводстве он не упоминался. Хотя основной целью существо- 
вавшего в 1747-1767 гг. университета в «Регламенте Академии наук и художеств в СанктПетербурге» и провозглашалась подготовка из «природных российских» людей ученых, в другом параграфе следовала оговорка: «...из Университета не одни только будут такие происходить, которые бы наполняли корпус Академической, но то бы весьма не мешало, ежели бы во всех состояниях, как военном, так и гражданском, внутрь и вне государства были Российские люди ученые» [37, с. 49]. Основной целью Академического училища также объявлялось воспроизводство научных кадров Академии: «первый и главный предмет» его был «доводить питомцев до такого совершенства в науках, дабы они могли со временем заступить места адъюнктов и действительных членов» [19, л. 79 об.]. Широкой подготовки, порождавшей спрос на выпускников Академического университета на военной и гражданской службе, от нового училища уже не ожидалось. Вместо этого рекомендовалось при выпуске из училища учеников, достигших 21 или 22 лет, если они оказывались «неспособны при Академии остаться, и тех, для которых места не будет, стараться Совету доставлять им другия места, дабы они по выпуске не претерпевали нужды» [19, л. 79 об.]. Чуть шире был сформулирован один из пунк- тов Устава Орлова: «Отпущенных от Академии воспитанников со свидетельствами о их порядочном поведении и о успехах в науках определять по их желаниям и способности на порожния места во всякую наши гражданския и другия службы безпрепятственно» [19, л. 60].

Из двадцати глав Устава Орлова училищу были посвящены полностью четыре (с четырнадцатой по семнадцатой): «О училище», «О надзирателе и Надзирательнице училища», «О учителях и учительницах» и «О экзаминах или искусах». Они задавали самое общее направление реформы и текстуально почти перекликались с уставами других учебных заведений, реформируемых И.И. Бецким. Для сравнения возьмем два из них, предназначенных для мальчиков, - «Устав Императорскаго Шляхетнаго Сухопутнаго Кадетскаго Корпуса» и «Высочайше утвержденный план Воспитательнаго училища из купеческих детей для коммерции» (см. таблицу) [6; 18].

Очевидно, что их тексты перекликаются, и Устав Орлова, хотя и выступает самостоятельным текстом, по духу полностью соответствовал реформе И.И. Бецкого. Важными «маркерами» его реформы являлись трехлетние образовательные циклы и прием учащихся в возрасте не старше пяти-шести лет.

\section{Сравнение уставных документов 1766-1772 гг., предназначенных для учебных заведе-} ний Академии наук, Кадетского корпуса и Коммерческого училища

Comparison of statutory documents of 1766-1772 intended for educational institutions of the Academy of Sciences, the Cadet Corps and the Commercial School

\begin{tabular}{|c|c|c|}
\hline Устав Орлова (1770) & Устав Кадетского корпуса (1766) & План Коммерческого училища (1772) \\
\hline $\begin{array}{l}\text { «Принимать во училище чрез } \\
\text { каждый (так в источнике. - } \\
T . \text { К.) три года по дватцати } \\
\text { мальчиков не старее пяти или } \\
\text { шести лет. <... ...По оконча- } \\
\text { нии же приема упалых мест не } \\
\text { наполнять до новаго срока ни } \\
\text { под каким видом» }\end{array}$ & $\begin{array}{l}\text { «Совету принимать в Корпус } \\
\text { отроков сто из природных рос- } \\
\text { сийских и двадцать из завое- } \\
\text { ванных Лифляндской, Фин- } \\
\text { ляндской и Эстляндской про- } \\
\text { винций, каждого принимать от- } \\
\text { нюдь не старее как по шестому } \\
\text { году, ежели по приеме случать- } \\
\text { ся убылые места, комплекто- } \\
\text { вать оные только в первом году, } \\
\text { а в следующие потом два года } \\
\text { ни единого более не принимать, } \\
\text { но оный прием возобновлять по } \\
\text { прошествии трех лет» }\end{array}$ & $\begin{array}{l}\text { «Учреждается сие училище на сто } \\
\text { мальчиков из купеческих детей, } \\
\text { принимаемых чрез каждые три } \\
\text { года по дватцати. <..> Следуя } \\
\text { конфирмованным учреждениям, } \\
\text { принимать мальчиков из природ- } \\
\text { ных Российских, Апреля с } 21 \text { чис- } \\
\text { ла, не моложе 5-ти по 6-му году» }\end{array}$ \\
\hline $\begin{array}{l}\text { «Дети должны быть здоровые. } \\
\text { Увечных и больных не прини- } \\
\text { мать; в чем освидетельствовать } \\
\text { их наперед с прилежностию } \\
\text { врачу или лекарю...» }\end{array}$ & $\begin{array}{l}\text { «Принимать их по осмотрам и } \\
\text { свидетельствам от докторов и } \\
\text { лекарей о здоровом их сложе- } \\
\text { нии и безвредном состоянии» }\end{array}$ & $\begin{array}{l}\text { «Всех оных прием, разумеется, } \\
\text { должен быть по осмотрам и сви- } \\
\text { детельствам Доктора и Лекаря...» }\end{array}$ \\
\hline
\end{tabular}


Другие изменения отражали более общие взгляды на образование, характерные для исследуемого периода, однако в уставах реформируемых по модели И.И. Бецкого учебных заведений схожим образом были расставлены на них акценты.

Глава Устава Орлова «О надзирателе и Надзирательнице училища» была наполнена советами: «исправляя пороки вкоренять в них добронравие к чему они особливо добрым своим примером и советом много способствовать могут» $[19$, л. 80]. Глава «О учителях и учительницах» предписывала «стараться при охотить и привлечь детей к учению, сделав им оное приятным. Чего ради недолжно отягощать их учением» $[19$, л. 81]. В главе «О экзаминах или искусах» предусматривались ежемесячные и полугодовые «искусы», которые до 15 или 16 лет должны были проходить при одном или нескольких из профессоров или адъюнктов, надзирателе, надзирательнице и учителях с награждением книгами «и другими вещами, приличными их упражнениям». Более старшим «воспитанникам» полагались медали [19, л. 82]. Наказания телесные предполагалось не использовать больше не только для учащихся, но и для нижних служителей Академии [19, л. 84]. А если ученик «от кротких наказаний не исправится, то представлять Совету, который примет средства удалить таковыя соблазнительныя примеры от глаз юношества» [19, л. 81].

Несмотря на идейную и отчасти структурную близость Устава Орлова аналогичным уставам других учебных заведений, реформируемых по программе И.И. Бецкого, В.Г. Орлов осуществил все же независимую работу над ним. Еще 16 апреля 1767 г., в связи с деятельностью Уложенной комиссии, В.Г. Орлов попросил собрать «учреждении лутчих школ и лутчих университетов и выписать оныя как скоро можно будет на мой щет» [22, с. 363]. Пока, однако, не удалось восстановить прямой преемственности между известными уставами европейских учебных заведений и Уставом Орлова. Понятно лишь, что текст Устава Орлова содержит отсылки к некоторым источникам, созданным при непосредственном участии Екатерины II, например к «Генеральному учреждению о воспитании обоего пола юношества».
Положения, отраженные в Уставе Орлова, вводились в практическую деятельность учебных заведений Академии наук не сразу, а на протяжении 1769-1771 годов. С начала 1769 г. были введены обязательные полугодовые экзамены, которым подвергали всех казеннокоштных гимназистов - как малолетних, так и взрослых. До этого времени экзамены для гимназистов проводились от случая к случаю, тут же они стали регулярными [1, л. 24]. В ноябре 1769 г. было введено награждение гимназических учеников книгами, также ставшее регулярным [1, л. 118]. О награждении медалями сведений найти не удалось. 20-я глава Устава Орлова устанавливала: «Священник, который в Училище Академическом детей обучать будет закону Божию, и службу Божию отправлять должен как скоро сыщется удобное к церкви при Академии место» [19, л. 83 об.]. Устройством церкви при Академической гимназии 12 января 1771 г. активно начал заниматься иеромонах Кирилл. Освящение домовой церкви во имя митрополита Петра в Строгановом доме состоялось 21 декабря 1771 года.

Устав Орлова не устанавливал определенной структуры классов, указывая только на занятия учеников в период от 12 до 15 лет, когда они передавались от надзирательницы к надзирателю: «Обучаться им словесным наукам, как то разумению иностранных языков, а особливо своего природнаго; иметь понятие о географии и истории вообще, в российской же географии и истории упражняться предпочтительно; отменно прилежать к фисике и мафиматике, а паче всего смотреть, что бы наставление в законе церкви нашей преподаваемое им было рачительно. <...> ...Иметь всякия невинныя забавы, воспитанию пристойныя, как то танцованье, плаванье и тому подобныя телесныя движения» [19, л. 79]. Направление занятий в училище (упор на знание родного языка, географии и истории своей страны, внимание к физическим упражнениям, критическое отношение к наказаниям) вполне соответствовало идеям руссоистской школы, в том числе И.Б. Базедова. Эти идеи поддерживал и А.-Р. Санчес, который вполне мог быть одним из каналов их передачи. А.-Р. Санчес к этому времени проживал в Париже, ранее он имел опыт работы врачом в Кадетском 
корпусе в Петербурге. В 1762 г. он был назначен почетным академиком Петербургской академии наук и активно переписывался в период проведения реформы учебных заведений с И.И. Бецким, В.Г. Орловым, Я. Штелиным и др. [8, с. 220-224; 43].

Главное изменение в жизни учебного заведения было связано с восстановлением чтения ряда курсов лекций, соответствующих университетской программе. При этом создавалась новая система подготовки, лишь отчасти продолжавшая традиции Академического университета. С 1747 по 1767 г. университет имел свой штат, состоящий из ректора и пяти профессоров, специализирующихся по предметам философского факультета европейских университетов: ректор университета и историограф, профессор элоквенции и стихотворства, профессор логики, метафизики и нравоучительных наук, профессор древностей и истории литеральной, профессор математики и физики, профессор истории политической и юриспруденции [37, с. 58]. Обычно студенты около трех лет слушали общие для всех лекции, после чего начинали специализироваться или у профессоров, или у академиков четырех классов Академии (астрономического, физического, физико-математического и математического). Согласно Регламенту 1747 г., обучение происходило на латинском или русском языке, и обязательность латыни сдерживала численность студентов.

После 1770 г., поскольку академиков по гуманитарным дисциплинам (принадлежащим к расширившемуся в то время и нередко разделяемому в университетах на два отделения философскому факультету) не было, получить законченное университетское образование по этим дисциплинам было невозможно. Отдельные курсы философского факультета, без которых по устоявшимся представлениям того времени невозможно было слушать высшие науки, были перенесены в программу училища и читались его преподавателями. Например, логику преподавал инспектор Л.И. Бакмейстер, а древности и латинских авторов - конректор И.Г. Штриттер [21, л. 2]. Лекции академиков превращались в публичные. § 23 главы 2 гласил: «Всякии месяц по два раза читать лекции и делать опыты из Экспериментальной фисики; так же и из дру- гих наук. Смотреть при том того, что бы были оныя внятны и достойным любопытства слушателей» $[19$, л. 66]. Порядок чтения лекций и лекторов должны были определять классы Академии, а язык прописывался отдельным $\S 25:$ «Как скоро возможно будет, то читать оныя на российском, а до того времяни на французском или немецком языках» $[19$, л. 66].

Формально нигде в Уставе Орлова не сказано, что воспитанники училища должны были посещать эти лекции. Для них предусматривалась индивидуальная подготовка под руководством академиков. § 22 Устава Орлова гласил: «Действительные члены приданным им адъюнктам и воспитанникам преподают в науках наставления, и стараются в оных довесть их до совершенства» [19, л. 66]. Устав Орлова вменял в особую заслугу действительным членам, если они подготовят академика из адьюнкта или адъюнкта из воспитанника [19, л. 60 об.].

На практике лекции академиков возобновились в 1770 г. на латинском и немецком языках, они были посвящены механике, оптике, астрономии, химии и натуральной истории и сначала читались старшим гимназистам, которые через три года были либо выпущены студентами, либо переименованы в элевы [2, л. 87; 11, с. 288-290]. Публичные лекции начались только в 1776 г. [34, с. 17-21]. А «чтобы гимназисты в хождении в зад и вперед не теряли напрасно времени, определено вышепомянутыя лекции читать в аудитории при Гимназии» [7, л. 15]. До 1778 г. такие лекции посещали гимназисты с особого разрешения, однако, когда они покидали Академическое училище, им давался аттестат, где присваивалось звание студента.

Наименование элевами также вводилось новым уставом. В главе «О училище» указывал, что ученики, достигшие 14-15 лет будут «называтца елевами, или воспитанниками, и обучаться по рассмотрению собрания наукам под предводительством действительных членов или адъюнктов» $[19$, л. 79$]$. Откуда в русскоязычный устав попало слово «элев», можно только догадываться. С французского языка élève переводится как «воспитанник, ученик», и во французских текстах, естественно, так называли академических студентов и раньше. Это слово использовалось М.В. Ло- 
моносовым уже в проектах регламента Академии наук первой половины XVIII в., где он называл элевами тех учеников академиков, кто еще ниже адъюнктов $[15$, с. 87,147$]$. В 1768 г. оно попало и в русский перевод трактата барона Я.Ф. Бильфельда «Наставления политические», в которых упоминаются элевы как ученики Академии [11, с. 278-279.]. Тем не менее с 1773 г., ровно через три года после введения устава (во всех учебных заведениях, подвергнувшихся реформе при И.И. Бецком, вводились трехлетние образовательные циклы), при Академии наук появились первые элевы: М.Е. Головин, Ф.П. Моисеенко и К. Флоринский [3, л. 99].

По-видимому, реформа учебных заведений, произведенная согласно неконфирмованному уставу, вызывала вопросы уже у современников описываемых событий. После 1782 г. (вполне вероятно, что специально для Сенатской комиссии) неустановленным пока сотрудником Академии наук было составлено «Объяснение об Университете и Гимназии», где рассматриваемый период характеризовался так: «Между тем преподаваемы были наставления в Математике, Химии, анатомии и Истории Натуральной, так что хотя Гимназия и Университет, применяяся по вновь сочиненному Уставу, и назывались одним именем Училище Академии; но составляющие оное воспитанники обучались большому числу Наук, нежели в Регламенте об Университете предписано, и таким наипаче, кои по вновь сочиненному Уставу нужны были для Академии» [21, л. 2].

Результаты. Итак, «Привилегии и Устав Санктпетербургской императорской Академии наук», написанные директором Академии наук В.Г. Орловым, несмотря на то, что остались неконфирмованным документом, были положены в основу реформы Академии наук, проводимой в 1769-1771 годах. В числе других преобразований на базе Академической гимназии создавалось училище для подготовки научных кадров по заново установленным направлениям деятельности Академии наук - математическому и физическому. В нем реализовывалась образовательная и воспитательная модель, характерная для других учебных заведений, реформируемых И.И. Бецким. Некоторые базовые предметы философского факультета преподавались там же. Таким образом, преобразования окончательно зафиксировали отсутствие при Академии наук расформированного в 1767 г. университета, но сохранили процесс подготовки научных кадров, в которую была заложена и ступень высшего образования.

\section{ПРИМЕЧАНИЕ}

1 Доклад Дж. Ларокки (Universita degli Studi di Firenze / Universita di Macerata) «Jacob von Stдhlin and the Imperial Academy of Sciences: New Materials» на Международной конференции Группы по изучению России XVIII в. (SGECR International Conference), представленный 9 июля 2018 г. в Страсбурге.

\section{СПИСОК СОКРАЩЕНИЙ}

ОР РНБ - Отдел рукописей Российской национальной библиотеки.

ПСЗРИ - Полное собрание законов Российской империи, с 1649 года.

РГАДА - Российский государственный архив древних актов.

СПбФ АРАН-Санкт-Петербургский филиал Архива РАН.

\section{СПИСОК ЛИТЕРАТУРЫ}

1. Выписки из журналов Комиссии Академии наук за 1769 год // СПбФ АРАН. - Р. IV. - Оп. 5. Д. 19-(1769).- 131 л.

2. Выписки из журналов Комиссии Академии наук за 1770 год // СПбФ АРАН. - P. IV. - Оп. 5. Д. 20-(1770).-144л.

3. Выписки из журналов Комиссии Академии наук за 1773 год // СПбФ АРАН. - P. IV. - Оп. 5. Д. 23-(1773).- 118 л.

4. Выписки из журналов Комиссии Академии наук за 1774 год // СПбФ АРАН. - P. IV. - Оп. 5. Д. 24-(1774).- 199л.

5. Выписки из журналов Комиссии Академии наук за 1782 год // СПбФ АРАН. - P. IV. - Оп. 5. Д. 32-(1782). - 255 л.

6. Высочайше утвержденный план Воспитательнаго училища из купеческих детей для коммерции // ПСЗРИ. Т. 19. 1770-1774. - [СПб.] : Печатано в Тип. ІІ Отд-ния Собств. Его Императ. Величества Канцелярии, 1830. - № 13916.

7. Дело о публичных лекциях в Академии наук 1775 августа 14 - 1776 февраль // СПбФ АРАН. Ф. 3. - Оп. 9. - Д. 290. - 20 л.

8. Идеал воспитания дворянства в Европе. XVII-XIX вв. / под ред. В. С. Ржеуцкого, И. И. Фе- 
дюкина, В. Береловича ; при участии М. Б. Лавринович. - М. : НЛО, 2018. - 480 с.

9. История Академии наук СССР. В 3 т. Т. 1. 1724-1803. - М. ; Л. : Изд-во АН СССР, 1958. $483 \mathrm{c}$.

10. Костина, Т. В. Когда и куда «пропал» Академический университет: реформа учебных заведений Академии наук 1765-1770 гг. / Т. В. Костина // Мавродинские чтения - 2018 : материалы Всерос. науч. конф., посвящ. 110-летию со дня рождения проф. Владимира Васильевича Мавродина / под ред. А. Ю. Дворниченко. - СПб. : Нестористория, 2018. - С. 510-513.

11. Костина, Т. В. Подготовка элит Российской империи в учебных заведениях Академии наук (1726-1805) / Т. В. Костина // Актуальное прошлое: взаимодействие и баланс интересов Академии наук и российского государства в XVIII - начале XX в. Очерки истории. В 2 кн. Кн. 1 / сост. и отв. ред. И. В. Тункина. - 2-е изд., испр. и доп. - СПб. : Реноме, 2018. - С. 207-302.

12. Костина, Т. В. Учебные заведения Академии наук: вопросы историографии и источниковедения / Т. В. Костина // Память о прошлом - 2018 : VII ист.-арх. форум, посвящ. 100-летию гос. арх. службы России (Самара, 15-17 мая 2018 г.) / сост.: О. Н. Солдатова (отв. сост.), Г. С. Пашковская. - Самара : РГА в г. Самаре, 2018. - С. 325-332.

13. Кулябко, Е. С. М.В. Ломоносов и учебная деятельность Петербургской Академии наук / Е. С. Кулябко. - М. ; Л. : Изд-во Акад. наук СССР, 1962. -216 с.

14. Летопись Российской Академии наук. Т. 1. 1724-1802 / гл. ред. Ю. С. Осипов ; отв. ред. Н. И. Невская. -СПб. : Наука, 2000. - 994 с.

15. Ломоносов, М. В. Полное собрание сочинений. В 11 т. Т. 10. Служебные документы. Письма. 1734-1765 гг. / М. В. Ломоносов. - М. ; Л. : Изд-во АН CCCP, 1957.-936 c.

16. Марголис, Ю. Д. Отечеству на пользу, а россиянам во славу : Из истории университетского образования в Петербурге в XVIII - начале XIX в. / Ю. Д. Марголис, Г. А. Тишкин. - Л. : Изд-во ЛГУ, 1988.-230, [2] c.

17. Марголис, Ю. Д. «Единым вдохновением». Очерки истории университетского образования в Петербурге в конце XVIII - первой половине XIX в. / Ю. Д. Марголис, Г. А. Тишкин. - СПб. : С.-Петерб. ун-т, 2000. $-228 \mathrm{c}$.

18. О напечатании и обнародовании новаго Устава Кадетскому сухопутному корпусу // ПСЗРИ. Т. 17. 1765-1766. - [СПб.] : Печатано в Тип. ІІ Отд-ния Собств. Его Императ. Величества Канщелярии, 1830. № 12741 .

19. О новом положении Академии наук // Архив Санкт-Петербургского Института истории РАН. - Ф. 36. - Оп. 1. - Д. 792. - 195 л.
20. О принятии Академии наук в собственное Ея Величества ведомство, для учинения в ней реформы // ПСЗРИ. Т. 17. 1765-1766. - [СПб.] : Печатано в Тип. II Отд-ния Собств. Его Императ. Величества Канцелярии, 1830. - № 12750.

21. «Объяснение об Университете и Гимназии», поданное в Академическое собрание // СПбФ АРАН. - Ф. 3. - Оп. 9. - Д. 1086. - 2 л.

22. Орлов-Давыдов, В. П. Биографический очерк графа В.Г. Орлова. Составлен внуком его графом В.П. Орловым-Давыдовым, главы 1-5 / В. П. Орлов-Давыдов // Русский архив. - 1908. - Вып. 7. С. $339-433$.

23. Письма кн. Н.Ю. Трубецкого сыну кн. П.Н. Трубецкому и прочим лицам, 1762-1764 гг. // ОР РНБ. - Собр. Михайловского. - Q 549. - 296 л.

24. Протоколы заседаний Конференции Академии наук с 1725 по 1803 г. Т. 2. 1744-1770. - СПб. : Тип. ИАН, 1899. - 886 с.

25. Рождественский, С. В. Очерки по истории систем народного просвещения в России в XVIII XIX веках. Т. 1 / С. В. Рождественский. - СПб. : Тип. М.А. Александрова, 1912. - X, 680, 48 с.

26. Санктпетербургския ведомости. - 1770. 4 мая (№ 36).

27. Санктпетербургския ведомости. - 1771. 1 марта (№ 17).

28. Санктпетербургския ведомости. - 1773. 29 марта (№ 26).

29. Санктпетербургския ведомости. - 1776. 19 февр. (№ 15).

30. Санктпетербургския ведомости. -1778 . 24 авг. (№ 68).

31. Санктпетербургския ведомости. - 1781. 23 февр. (№ 16).

32. Сердюцкая, О. В. Московский университет второй половины XVIII в. как государственное учреждение. Преподавательская служба / О. В. Сердюцкая. - М. : Спутник+, 2012. - 185 с.

33. Смагина, Г. И. Академия наук и Российская школа. Вторая половина XVIII в. / Г. И. Смагина. - СПб. : Наука, 2002. - 165 с.

34. Смагина, Г. И. Публичные лекции СанктПетербургской Академии наук во второй половине XVIII в. / Г. И. Смагина // Вопросы истории естествознания и техники. - 1996. - № 2. - С. 16-26.

35. Смагина, Г. И. Сподвижница Великой Екатерины. Очерки о жизни и деятельности директора Петербургской Академии наук княгини Екатерины Романовны Дашковой / Г. И. Смагина. - СПб. : Росток, 2006. - 360 с.

36. Смагина, Г. И. Устав Академии наук, составленный директором Академии графом В.Г. Орловым (1769 г.) / Г. И. Смагина // Академия наук в контексте историко-научных исследований в XVIII - первой половине ХХ в. : ист. очерки. -СПб., 2016.-С. 476-510. 
37. Уставы Академии наук СССР. 1724-1974 / отв. ред. Г. К. Скрябин. - М. : Наука, 1974. $207 \mathrm{c}$.

38. Феофанов, А. М. Студенчество Московского университета XVIII - первой четверти XIX века / А. М. Феофанов. - М. : Изд-во ПСТГУ, 2011. $253 \mathrm{c}$.

39. A History of the University in Europe. Vol. 2 . Universities in early modern Europe (1500-1800) / ed. by W. Rüegg. - Cambridge ; N. Y. : Cambridge University Press, 2007. - 693 p.

40. Alma mater Vilnensis : Vilnias universiteto istorijos bruožai / red. A. Bumblauskas [ir kt.]. - Vilnius : Vilniaus universiteto leidykla, 2012. - 1060 p.

41. Carneiro, A. Enlightenment Science in Portugal: The Estrangeirados and Their Communication Networks / A. Carneiro, A. Simoes, M.-P. Diogo // Social Studies of Science. - 2000. Vol. 30, № 4 (Aug.). - P. 591-619.

42. Feingold, M. University and Science in the Early Modern Period / M. Feingold. - Dordrecht : Springer Netherlands, 2006. - 308 p.

43. Head, B. F. Plan pour l'éducation d'un jeune seigneur russe. Manuscrito de Ribeiro Sanches (1766). Leitura, transcrição, tradução e comentários filológicos / B. F. Head. - Coimbra : Coimbra University Press, 2016. -282 p.

44. Imperialism and Science: Social Impact and Interaction / G. N. Vlahakis [et al.]. - Santa Barbara ; Denver; Oxford : Springer : Dordrecht, 2006. - 398 p.

45. Madariaga, I. de. TheFoundation of the Russian Educational System by Catherina II / I. de Madariaga // The Slavonic and East European Review. - 1979. Vol. 57, № 3 (July). -P. 369-395.

\section{REFERENCES}

1. Vypiski iz zhurnalov Komissii Akademii nauk za 1769 god [Extracts from the Journals of the Commission of the Academy of Sciences for 1769]. $S P b F$ ARAN [Archive of the Russian Academy of Sciences, Saint Petersburg Branch], R. IV, Op. 5, D. 19(1769). 1311.

2. Vypiski iz zhurnalov Komissii Akademii nauk za 1770 god [Extracts from the Journals of the Commission of the Academy of Sciences for 1770]. $S P b F A R A N$ [Archive of the Russian Academy of Sciences, Saint Petersburg Branch], R. IV, Op. 5, D. 20(1770). 1441.

3. Vypiski iz zhurnalov Komissii Akademii nauk za 1773 god [Extracts from the Journals of the Commission of the Academy of Sciences for 1773]. $S P b F$ ARAN [Archive of the Russian Academy of Sciences, Saint Petersburg Branch], R. IV, Op. 5, D. 23 (1773). 1181.
4. Vypiski iz zhurnalov Komissii Akademii nauk za 1774 god [Extracts from the Journals of the Commission of the Academy of Sciences for 1774]. $S P b F$ ARAN [Archive of the Russian Academy of Sciences, Saint Petersburg Branch], R. IV, Op. 5, D. 24(1774). 1991.

5. Vypiski iz zhurnalov Komissii Akademii nauk za 1782 god [Extracts from the Journals of the Commission of the Academy of Sciences for 1782]. $S P b F$ ARAN [Archive of the Russian Academy of Sciences, Saint Petersburg Branch], R. IV, Op. 5, D. 32(1782). 2551.

6. Vysochayshe utverzhdennyy plan Vospitatelnago uchilishcha iz kupecheskikh detey dlya kommertsii [The Highly Approved Plan for the Educational Commerce School for Merchant Children]. PSZRI. T. 19. 19. 1770-1774 [The Complete Collection of Laws of the Russian Empire. Vol. 19. 1770-1774]. Saint Petersburg, Pechatano v Tipografii II Otdeleniya Sobstvennoy Ego Imperatorskogo Velichestva Kantselyarii, 1830, no. 13916.

7. Delo o publichnykh lektsiyakh v Akademii nauk 1775 avgusta $14-1776$ fevral [The Case of Public Lectures at the Academy of Sciences August 14, 1775 February, 1776]. SPbF ARAN [Archive of the Russian Academy of Sciences, Saint Petersburg Branch], F. 3, Op. 9, D. 290. 201.

8. Rzheutskiy V.S., Fedyukin I.I., Berelovich V., Lavrinovich M.B., eds. Ideal vospitaniya dvoryanstva v Evrope: XVII-XIX vv. [The Ideal of Educating the Nobility in Europe: $17^{\text {th }}-19^{\text {th }}$ Centuries]. Moscow, NLO Publ., 2018. 480 p.

9. Istoriya Akademii nauk SSSR. T. 1 (17241803) [History of the USSR Academy of Sciences. Vol. 1 (1724-1803)]. Moscow, Leningrad, Izd-vo AN SSSR, 1958. 483 p.

10. Kostina T.V. Kogda i kuda «propal» Akademicheskiy universitet: reforma uchebnykh zavedeniy Akademii nauk 1765-1770 gg. [When and Where Did the Academy's University "Disappear": Reform of the Education Institutions of the Academy of Sciences 1765-1770]. Dvornichenko A.Yu., ed. Mavrodinskie chteniya - 2018: materialy Vseros. nauch. konf., posvyashch. 110-letiyu so dnya rozhdeniya prof. Vladimira Vasilyevicha Mavrodina [Mavrodin Readings 2018: Materials of the All-Russian Scientific Conference Dedicated to the $110^{\text {th }}$ Anniversary of Professor Vladimir Vasilyevich Mavrodin]. Saint Petersburg, Nestor-istoriya Publ., 2018, pp. 510-513.

11. Kostina T.V. Podgotovka elit Rossiyskoy imperii v uchebnykh zavedeniyakh Akademii nauk (1726-1805) [The Training of the Elites of the Russian Empire in the Education Institutions of the Academy of Sciences (1726-1805)]. Tunkina I.V., ed. Aktualnoe proshloe: vzaimodeystvie i balans interesov Akademii 
nauk $i$ rossiyskogo gosudarstva $v$ XVIII - nachale $X X$ v. Ocherki istorii. V $2 \mathrm{kn} . \mathrm{Kn} .1$ [Actual Past: Interaction and Balance of Interests of the Academy of Sciences and the Russian State in the $18^{\text {th }}-$ Early $20^{\text {th }}$ Centuries. History Essays. In 2 Books. Book 1]. Saint Petersburg, Renome Publ., 2018, pp. 207-302.

12. Kostina T.V. Uchebnye zavedeniya Akademii nauk: voprosy istoriografii i istochnikovedeniya [Education Institutions of the Academy of Sciences: Questions of Historiography and Source Study]. Soldatova O.N., Pashkovskaya G.S., eds. Pamyat o proshlom - 2018: VII iSaint-arkh. forum, posvyashch. 100-letiyu gos. arkh. sluzhby Rossii (Samara, 1517 maya 2018 g.) [Memory of the Past - 2018. $7^{\text {th }}$ Historical and Archive Forum Dedicated to the $100^{\text {th }}$ Anniversary of the State Archival Service of Russia (Samara, May 15-17, 2018)]. Samara, RGA v g. Samare, 2018, pp. 325-332.

13. Kulyabko E.S. M.V. Lomonosov i uchebnaya deyatelnost Peterburgskoy Akademii nauk [M.V. Lomonosov and the Educational Activities of the Saint Petersburg Academy of Sciences]. Moscow, Leningrad, Izd-vo Akademii nauk SSSR, 1962. 216 p.

14. Osipov Yu.S., Nevskaya N.I., eds. Letopis Rossiyskoy Akademii nauk. T. 1. 1724-1802 [Chronicle of the Russian Academy of Sciences. Vol. 1. 1724-1802]. Saint Petersburg, Nauka Publ., 2000. 994 p.

15. Lomonosov M.V. Polnoe sobranie sochineniy. V 11 t. T. 10. Sluzhebnye dokumenty. Pisma. 1734-1765 gg. [Complete Works. In 11 Vols. Vol. 10. Service Documents. Letters. 1734-1765]. Moscow, Leningrad, Izd-vo AN SSSR, 1957. 936 p.

16. Margolis Yu.D., Tishkin G.A. Otechestvu na polzu, a rossiyanam vo slavu: Iz istorii universitetskogo obrazovaniya v Peterburge v XVIII-nachale XIXv. [For the Benefit of the Fatherland, and for the Glory of the Russians: From the History of University Education in Saint Petersburg in the $18^{\text {th }}-$ Early $19^{\text {th }}$ Centuries]. Leningrad, Izd-vo LGU, 1988. 230, [2] p.

17. Margolis Yu.D., Tishkin G.A. «Edinym vdokhnoveniem». Ocherki istorii universitetskogo obrazovaniya $v$ Peterburge v kontse XVIII - pervoy polovine XIX v. ["In One Inspiration". Essays on the History of University Education in Saint Petersburg in the Late $18^{\text {th }}-$ First Half of the $19^{\text {th }}$ Century]. Saint Petersburg. Sankt-Petersburgskiy universitet, 2000. $228 \mathrm{p}$.

18. O napechatanii i obnarodovanii novago Ustava Kadetskomu sukhoputnomu korpusu [About the Printing and Publication of the New Statute to the Cadet Ground Corps]. PSZRI. T. 17. 1765-1766 [The Complete Collection of Laws of the Russian Empire. Vol. 17. 1765-1766]. Saint Petersburg, Pechatano v Tipografii II Otdeleniya Sobstvennoy Ego Imperatorskogo Velichestva Kantselyarii, 1830, no. 12741 .
19. O novom polozhenii Akademii nauk [On the New Position of the Academy of Sciences]. Arkhiv Sankt-Peterburgskogo Instituta istorii RAN [Archive of Saint Petersburg Institute of the Russian Academy of Sciences], F. 36, Op. 1, D. 792.1951.

20. O prinyatii Akademii nauk v sobstvennoe Eya Velichestva vedomstvo, dlya uchineniya v ney reformy [On the Adoption of the Academy of Sciences in Her Majesty's Own Department, for Reform in It]. PSZRI. T. 17. 1765-1766 [The Complete Collection of Laws of the Russian Empire. Vol. 17. 1765-1766]. [Saint Petersburg], Pechatano v Tipografii II Otdeleniya Sobstvennoy Ego Imperatorskogo Velichestva Kantselyarii, 1830, no. 12750.

21. «Obyasnenie ob Universitete i Gimnazii», podannoe v Akademicheskoe sobranie ["Explanation of the University and Gymnasium" Filed in the Academic Assembly]. SPbF ARAN [Archive of the Russian Academy of Sciences, Saint Petersburg Branch], F. 3, Op. 9, D. 1086. 21.

22. Orlov-Davydov V.P. Biograficheskiy ocherk grafa V.G. Orlova. Sostavlen vnukom ego grafom V.P. Orlovym-Davydovym, glavy 1-5 [Biographical Essay of Count V.G. Orlov. Compiled by His Grandson Count V.P. Orlov-Davydov, Chapters 1-5]. Russkiy arkhiv, 1908, iss. 7, pp. 339-433.

23. Pisma kn. N.Yu. Trubetskogo synu kn. P.N. Trubetskomu i prochim litsam, 17621764 gg. [Letters of Prince N.Yu. Trubetskoy to His Son Prince P.N. Trubetskoy and Other Persons, 1762-1764]. OR RNB [Manuscript Department of the Russian National Library], Sobr. Mikhaylovskogo, Q 549.2961.

24. Protokoly zasedaniy Konferentsii Akademii nauk s 1725 po 1803 g. T. 2. 1744-1770 [The Journals of the Conference of the Academy of Sciences from 1725 to 1803 . Vol. 2. 1744-1770]. Saint Petersburg, Tipografiya IAN, $1899.886 \mathrm{p}$.

25. Rozhdestvenskiy S.V. Ocherki po istorii sistem narodnogo prosveshcheniya $v$ Rossii $v$ XVIII - XIX vekakh. T. 1 [Essays on the History of Public Education Systems in Russia in the $18^{\text {th }}-19^{\text {th }}$ Centuries. Vol. 1]. Saint Petersburg, Tipografiya M.A. Aleksandrova, 1912. $\mathrm{X}, 680,48 \mathrm{p}$.

26. Sanktpeterburgskiya vedomosti, 1770, May 4, no. 36.

27. Sanktpeterburgskiya vedomosti, 1771, March 1, no. 17.

28. Sanktpeterburgskiya vedomosti, 1773, March 29, no. 26.

29. Sanktpeterburgskiya vedomosti, 1776, February 19, no. 15.

30. Sanktpeterburgskiya vedomosti, 1778 , August 24, no. 68.

31. Sanktpeterburgskiya vedomosti, 1781, February 23, no. 16. 
32. Serdyutskaya O.V. Moskovskiy universitet vtoroy poloviny XVIII v. kak gosudarstvennoe uchrezhdenie. Prepodavatelskaya sluzhba [Moscow University of the Second Half of the $18^{\text {th }}$ Century as a Government Agency. Teaching Service]. Moscow, Sputnik+ Publ., 2012. 185 p.

33. Smagina G.I. Akademiya nauk i Rossiyskaya shkola. Vtoraya polovina XVIII v. [Academy of Sciences and Russian School. The Second Half of the $18^{\text {th }}$ Century]. Saint Petersburg, Nauka Publ., 2002. $165 \mathrm{p}$.

34. Smagina G.I. Publichnye lektsii SanktPeterburgskoy Akademii nauk vo vtoroy polovine XVIII v. [Public Lectures of the Saint Petersburg Academy of Sciences in the Second Half of the $18^{\text {th }}$ Century]. Voprosy istorii estestvoznaniya $i$ tekhniki [Studies in History of Science and Technology], 1996, no. 2, pp. 16-26.

35. Smagina G.I. Spodvizhnitsa Velikoy Ekateriny. Ocherki o zhizni i deyatelnosti direktora Peterburgskoy Akademii nauk knyagini Ekateriny Romanovny Dashkovoy [Associate of Great Catherine. Essays on the Life and Work of Director of the Saint Petersburg Academy of Sciences Princess Ekaterina Romanovna Dashkova]. Saint Petersburg. Rostok Publ., 2006. 360 p.

36. Smagina G.I. Ustav Akademii nauk, sostavlennyy direktorom Akademii grafom V.G. Orlovym (1769 g.) [The Charter of the Academy of Sciences Compiled by the Director of the Academy, Count V.G. Orlov (1769)]. Akademiya nauk v kontekste istoriko-nauchnykh issledovaniy $v$ XVIII - pervoy polovine XX v.: ist. ocherki [Academy of Sciences in the Context of Historical and Scientific Research in the $18^{\text {th }}-$ First Half of the $20^{\text {th }}$ Century. Historical Essays]. Saint Petersburg, 2016, pp. 476-510.
37. Skryabin G.K., ed. Ustavy Akademii nauk SSSR. 1724-1974 [Statutes of the Academy of Sciences of the USSR.1724-1974]. Moscow, Nauka Publ., 1974. 207 p.

38. Feofanov A.M. Studenchestvo Moskovskogo universiteta XVIII - pervoy chetverti XIX veka [Students of Moscow University of the $18^{\text {th }}-$ First Quarter of the $19^{\text {th }}$ Century]. Moscow, Izd-vo PSTGU, 2011.253 p.

39. Rüegg W., ed. A History of the University in Europe. Vol. 2. Universities in Early Modern Europe (1500-1800). Cambridge, New York. Cambridge University Press, 2007. 693 p.

40. Bumblauskas A., ed. Alma mater Vilnensis: Vilnias universiteto istorijos bruožai. Vilnius, Vilniaus universiteto leidykla, 2012. 1060 p.

41. Carneiro A., Simoes A., Diogo M.-P. Enlightenment Science in Portugal: The Estrangeirados and Their Communication Networks. Social Studies of Science, 2000, vol. 30, no. 4 (Aug.), pp. 591-619.

42. Feingold M. University and Science in the Early Modern Period. Dordrecht, Springer Netherlands, 2006. 308 p.

43. Head B.F. Plan pour l'éducation d'un jeune seigneur russe. Manuscrito de Ribeiro Sanches (1766). Leitura, transcrição, tradução e comentários filológicos. Coimbra, Coimbra University Press, 2016. $282 \mathrm{p}$.

44. Vlahakis G.N. et al. Imperialism and Science: Social Impact and Interaction. Santa Barbara, Denver, Oxford, Springer, Dordrecht, 2006. 398 p.

45. Madariaga I. de. The Foundation of the Russian Educational System by Catherina II. The Slavonic and East European Review, 1979, vol. 57, no. 3 (July), pp. 369-395.

\section{Information About the Author}

Tatiana V. Kostina, Candidate of Sciences (History), Researcher, Scientific-Historical Archive and Group of Source Studies, Saint Petersburg Institute of History of Russian Academy of Sciences, Petrozavodskaya St., 7, 197110 Saint Petersburg, Russian Federation, tatianav.kostina@gmail.com, https://orcid.org/0000-0002-5136-4328

\section{Информация об авторе}

Татьяна Владимировна Костина, кандидат исторических наук, научный сотрудник Научно-исторического архива и группы источниковедения, Санкт-Петербургский институт истории РАН, ул. Петрозаводская, 7, 197110 г. Санкт-Петербург, Российская Федерация, tatianav.kostina@gmail.com, https://orcid.org/0000-0002-5136-4328 